\title{
Energy storage systems for drilling rigs
}

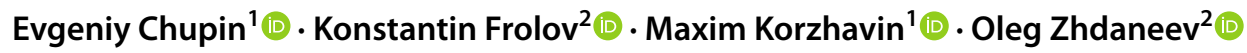

Received: 30 March 2021 / Accepted: 23 July 2021 / Published online: 29 December 2021

(c) The Author(s) 2021

\begin{abstract}
Energy storage systems are an important component of the energy transition, which is currently planned and launched in most of the developed and developing countries. The article outlines development of an electric energy storage system for drilling based on electric-chemical generators. Description and generalization are given for the main objectives for this system when used on drilling rigs isolated within a single pad, whether these are fed from diesel gensets, gas piston power plants, or 6-10 kV HV lines. The article studies power operating modes of drilling rigs, provides general conclusions and detailed results for one of more than fifty pads. Based on the research, a generic architecture of the energy storage module is developed, and an engineering prototype is built. The efficiency of using a hybrid energy accumulation design is proven; the design calls for joint use of Li-ion cells and supercapacitors, as well as three-level inverters, to control the storage system. The article reviews all possible options for connecting the system into a unified rig power circuit, and the optimum solution is substantiated. The research into the rig operating modes and engineering tests yielded a simplified mathematical model of an energy storage unit integrated into the power circuit of a drilling rig. The model is used to forecast the payoff period of the system for various utilization options and rig operating modes. The findings of this study can help to better understand which type of storage system is the most efficient for energy systems with temporary high load peaks, like drilling rigs.
\end{abstract}

Keywords Electric energy storage system $\cdot$ Inverter $\cdot$ Power distribution network $\cdot$ Microgeneration $\cdot$ Distributed generation $\cdot$ Renewable energy sources $\cdot$ Active consumer

\section{Introduction}

Energy storage systems (ESS) are an important component of the energy transition that is currently happening worldwide, including Russia: Over the last 10 years, the sector has grown 48 -fold with an average annual increase rate of 47\% (Kholkin, et al. 2019). According to various forecasts, by $2024-2025$, the global market for energy storage systems

Oleg Zhdaneev

Zhdaneev@ rosenergo.gov.ru

Evgeniy Chupin

e.chupin@momentum.ru

Konstantin Frolov

Frolov@rosenergo.gov.ru

Maxim Korzhavin

m.korjavin@momentum.ru

1 OOO NTC "Privodnaya Tekhnika", Chelyabinsk city, Russia 454007

2 Russian Energy Agency of Ministry of Energy of the Russian Federation, 105/1 Mira ave, Moscow city, Russia 129085 will reach 50-100 GW, which equals USD 80 billion. Over the recent years, development of ESS has been driven by development of non-conventional renewable energy sources (RES) (Zhdaneev 2020). The maximum capacity of the Russian ESS market is 10-15 GW up until 2030 (Kholkin, et al. 2019).

Currently, five energy storage technologies have been commercially developed: mechanical, electrochemical, thermal, electrical, and chemical (Andrey et al. 2020). According to the technology development report (Andrey et al. 2020) of the European Energy Commission, electrochemical ESS is the second most developed and used technology of production after pumped-storage units. ESS installed for end-consumers (prosumers) (Brown et al. 2020) downstream of the power meters, i.e., on the prosumer side, plays an increasingly important role, including in the oil and gas industry.

The work to develop electric energy storage systems for drilling rigs has been underway worldwide for the last 5 years, however, mainly targeting isolated offshore rigs. 
The first example of practical use of an ESS in the oil and gas industry was a joint project of Woodside Energy and ABB Ability (Baccino et al. 2018)—a PowerStore system with a rated capacity of $1 \mathrm{MW}$ and a storage capacity of $1 \mathrm{MWh}$, installed at the Australian Goodwyn Alpha offshore platform in 2017. The platform production capacity is up to 36 and $11 \mathrm{kTpD}$ of gas and gas condensate, respectively. The platform is equipped with four $3.2 \mathrm{MW}$ gas turbine power units, a total of $12.8 \mathrm{MW}$. Confirmed ESS operation results in 2019: saving 3,000 tons of diesel fuel and reducing $\mathrm{CO}_{2}$ emissions by 7,500 tons. Thus, ESS replaced 1 out of 4 existing gas turbine generators and reduced the emergency diesel generator operating time.

The next offshore ESS project was developed by Seadrill/Northern Drilling, Siemens, Kongsberg Maritime, and DNV GL (Northern Drilling's West Mira first rig to receive DNV GL Battery (Power) 2019), and commissioned on the West Mira semi-submersible rig in the North Sea in 2018. This ESS consisted of four 1.5 MW modules, with total capacity of $6 \mathrm{MW}$. The rig power unit consisted of six 5.5 MW DPSs. As a result, $42 \%$ saving of diesel fuel and $12 \%$ reduction in $\mathrm{CO}_{2}$ emissions are currently reported.

In 2020, Maersk (Energy and delivers energy storage, 2021) implemented the world's third project of using an ESS in offshore oil and gas production on a Maersk Intrepid CJ70 jack-up drilling rig, also operating in the North Sea. The total capacity of the rig power unit is $11.6 \mathrm{MW}$. The monthly saving of diesel fuel was $25 \%$, and $\mathrm{CO}_{2}$ emissions were reduced by $25 \%$. In its basic specifications, this ESS was similar to the Australian Woodside Energy and ABB Ability ESS project.

In the beginning of the article, feasibility of wide use of ESS on drilling rigs is substantiated. Conclusions are then made following 2017-2019 hands-on studies of power modes on a number of rigs. Results of these studies laid a foundation for development of an experimental ESS unit with a control system based on a 3-level invertor. Explanation is given for the optimum way to integrate the ESS into a rig power circuit. After field testing, feasibility of using ESS in drilling is proven, and bare-bone specifications for a serial-produced ESS are calculated.

\section{ESS for drilling rigs}

If certain pricing rates are achieved, ESS may provide extremely effective solutions for the following power supply objectives for the Russian oil and gas industry:

a) Improving the power quality. Despite the lack of RES, the majority of Russian consumers experience the same problems with power dips as networks with a large share of RES do due to the length and bad state of lines. ESS provides reliable power supply and postpones investments in upgrades of the existing networks and building new ones;

b) Using ESS as storage systems downstream of the power meter to optimize energy supply costs. There are several reasons to install a storage system, ranging from the requirements for uninterrupted supply to the possibility of reducing costs by lowering the consumption peaks.

In Russia, deep drilling rigs (Zhdaneev and Frolov 2020) are among the most energy-intensive facilities with an installed total capacity of 3-5 MW.

Extensive experience in designing and maintaining rig control and power supply systems has shown that the load pattern is characterized by a short-term high energy consumption with a high-power rise rate, which requires a larger number of simultaneously operating diesel power stations (DPS), or gas piston or gas turbine units (Pavković et al. 2016). As for the rigs, this energy consumption mode is most typical of run-in-hole/put-out-of-hole operations (RIH/ $\mathrm{POOH})$.

Based on average daily power consumption statistics and load diagrams for various rig operating modes at more than fifty pads equipped with DPS, it was proposed to improve the energy efficiency of individual DPS-powered rigs by introducing energy storage systems (Fig. 1).

The use of energy storage systems in well drilling will reduce the costs of powering self-contained facilities due to the following benefits:

1. Capital costs of powering drilling rigs are reduced with removal of one or two 1 MW DPS (of 4-5 typically used) with high self-containment of operation, i.e., settings check once per shift. Also, the ESS does not need extra labor since it is maintained by the rig's power/ electronics engineer,

2. The diesel fuel consumption will be reduced by up to 20-30\% (depending on the ESS capacity) through equalizing the ESS load with the overall positive economic effect compared to the exclusively DPS-powered drilling rigs,

3. The DPS life cycle increases by up to $40 \%$ due to the peak load compensation and limiting the diesel generator load growth rate,

4. The service life of frequency converters, the momentum inverters, and storage batteries is at least 10 years, and 25 years for other elements,

5. The energy efficiency of drilling is improved through reduced operating costs for diesel fuel and electricity. The payoff period is $2-5$ years due to savings on diesel fuel and DPS maintenance, depending on the ESS 
Fig. 1 Energy storage system composition

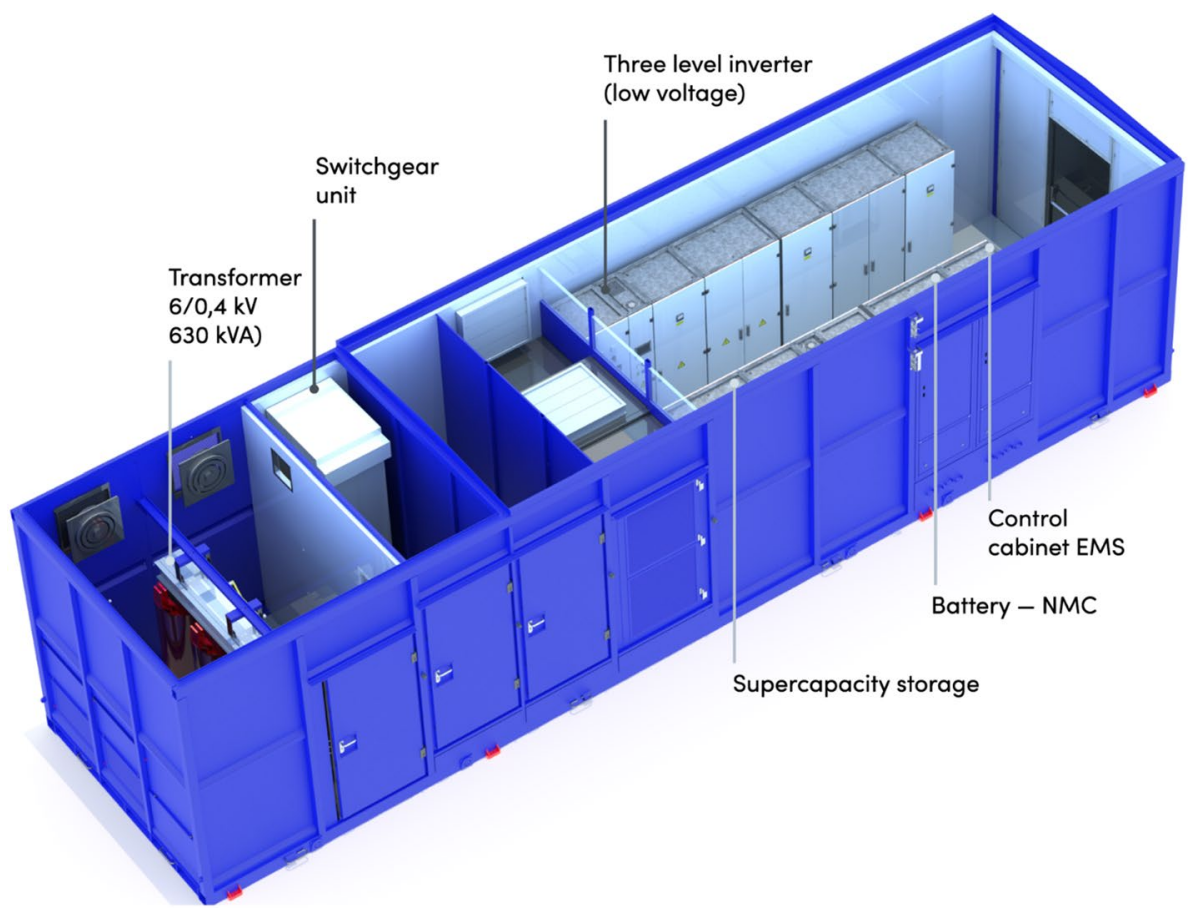

capacity, the drilling process chart, and the average annual maintenance costs.

It also becomes possible to compensate reactive power and intensively support the network when its voltage value and frequency deviate due to the energy accumulation and further supply to the line since ESS can be integrated into all rig power systems fed from 6 to $0 \mathrm{kV}$ HV lines (Dehghani et al. 2020).

ESS will allow oil and gas companies to operate modern energy-intensive (3-5 MW) rigs on weak HV lines and rigs far from power substations without a DPS. The DR peak load-factoring by ESS allows eliminating voltage slumps in weak lines, which positively affects neighboring network consumers such as submersible pumps in the field. ESS will significantly reduce the environmental footprint by reducing harmful $\mathrm{CO}_{2}$ emissions from 3-5 MW DPSs by up to $25 \%$ annually (Dai et al. 2019).

An energy source permanently integrated into the rig circuit will allow drilling contractors to compensate for voltage dips and surges, which will reduce emergency shutdowns and downtime of drilling equipment (Chervonchenko and Frolov 2020), minimize drilling hazards, and improve the DPS operation stability.

Furthermore, an ESS is easily scalable in power, storage capacity, and voltage and is built on uniform modules.
All of the advantages above are very relevant for both offshore and onshore drilling, including operations in the harsh conditions of the Russian North (Zhdaneev et al. 2020).

\section{Studying power modes of rigs}

In 2017-2019, power modes of twenty drilling rigs were studied. The study involved measuring the quality and quantity of the energy consumed by diesel generator-powered rigs, the generator running times, and the diesel fuel consumption at various well construction stages. The study results were generalized for rigs by different manufacturers and with varying load capacity.

All measurements were performed to further define the most optimum storage unit and inverter capacity, and the storage unit connection circuit. These studies have shown that the average daily rig power consumption is within $350-500 \mathrm{~kW}$, depending on the rig type and well complexity. Here, the optimum storage unit capacity in terms of economy and payoff period (4 years max.) has been determined, which varies within $150-350 \mathrm{kWh}$. All the while, a unit with supercapacitors should be used to compensate for dynamic operating modes.

Table 1 represents the power consumption study results for a 320 ton capacity rig.

Figure 2 shows the number of diesel gensets simultaneously operated at the rig at hand. The figure shows modes

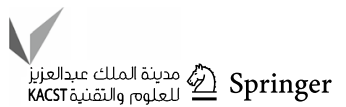


Table 1 Basic power consumption study results for a 320 t capacity rig

\begin{tabular}{lll}
\hline Parameter & UoM & Value \\
\hline DPS energy & $\mathrm{kWh}$ & 371,520 \\
DPS running time & $\mathrm{h}$ & 966 \\
Fuel consumption & $\mathrm{L}$ & 113,000 \\
Max. braking resistance power & $\mathrm{kW}$ & 1,038 \\
Max. braking resistance energy & $\mathrm{kWh}$ & 4.4 \\
Total braking resistance energy dur- & $\mathrm{kWh}$ & $2,400(0.65 \%$ \\
ing drilling & & of the total \\
& & yield $)$ \\
\hline
\end{tabular}

Fig. 2 The use of diesel generators as part of $5000 / 320 \mathrm{DR}$, well pad \# 23 of the Kondinskoye Field

Fig. 3 Diagram of the DW drive load in the RIH/POOH mode with maximum peak power requiring simultaneous operation of up to four diesel generators.

The study allows determining the possibility of improving the energy efficiency of drilling (reducing the costs of diesel fuel and the generator running time) by up to $30 \%$ by equalizing the generator load and setting the optimum load mode, at which the best fuel consumption is achieved. Loads are equalized by using modern ESS accumulating the energy between the consumption periods and supplying it at peak hours.

The effect is determined by the fact that a diesel engine consumes fuel most efficiently at a load of over 50\% (Daho et al. 2013). However, sharply changing loads during operation of the drawworks (DW) require additional diesel generators to cover the peak loads, which usually keeps one or two generators underloaded for a considerable time. Figure 3
Drilling
P, MW

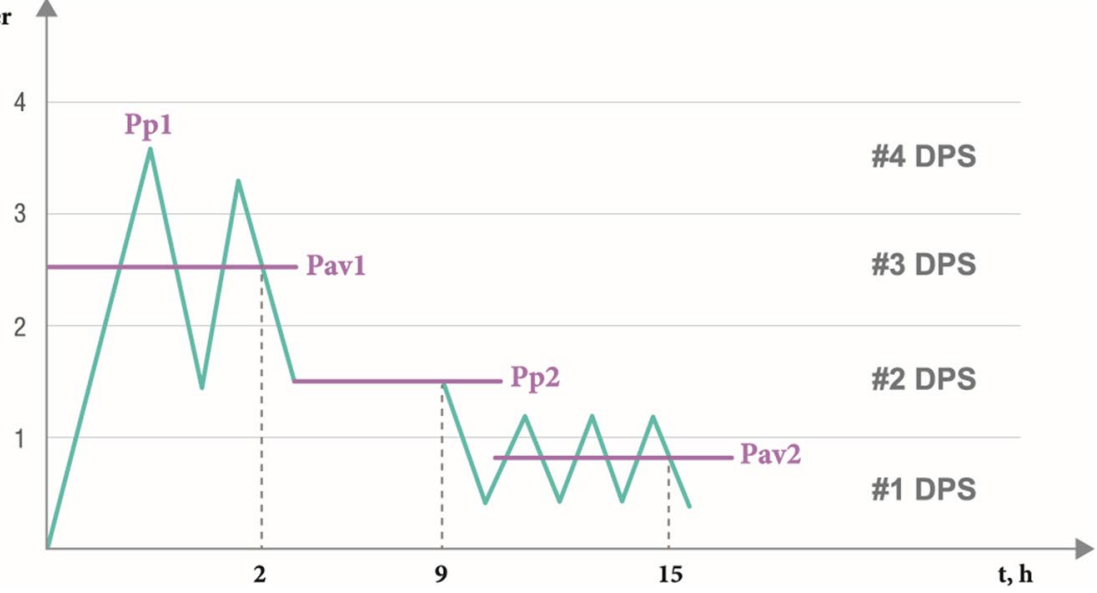

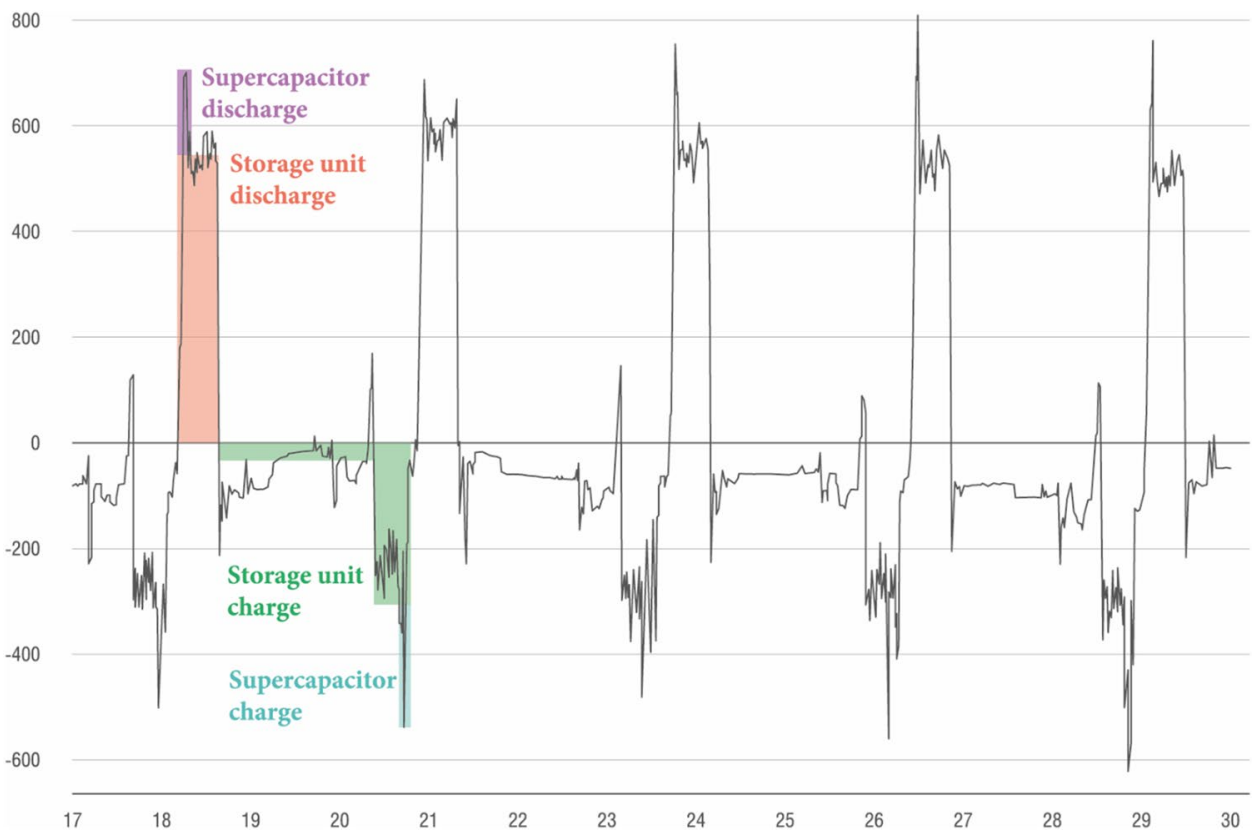


shows a typical diagram of power consumption during DW operation.

Analysis of the approximated load diagram in the RIH/ $\mathrm{POOH}$ mode has shown that under these conditions, a hybrid electric energy storage design (comprising a Li-ion battery and supercapacitors) is the most efficient one. It utilizes the advantages of both types of storage: A supercapacitor provides a high peak discharge power and storage resource, and a Li-ion battery ensures long-term support of the load due to its high storage capacity (Zhuk et al. 2013).

When using inverters in grid energy storage units, the quality of the power fed back to the grid is important and must meet the requirements of the EN 50,160:2010 (NEQ). The standard regulates the harmonic components in the output voltage generated by the inverter rather strictly. Under these conditions, an inverter built on a three-level NPC (Neutral Point Clamped) topology is the most relevant choice (Pouresmaeil et al. 2012). The main advantages of a three-level inverter over a two-level one are as follows:

1. Reduced losses in the output filtering and matching circuits (such as sine filters and matching line chokes) due to the improved first harmonic output of the generated voltage. (The line and phase voltage waveforms are close to a sinusoid.)

2. Reduced network harmonics and other negative factors affecting the output voltage and current quality.

3. Reduced dynamic losses in power transistors.

4. Improved weight and size of sine filters and matching line chokes.

In 2020, an engineering prototype for a drilling ESS was built in the form of a 20 ton container with a control system based on three-level inverters.

The main components of the engineering ESS prototype are:

1. A three-level MT2000 MOMENTUM inverter,

2. A $133-\mathrm{kWh}$ NMC storage battery,

3. A 4-kW supercapacitor,

4. A 6/0.4-kV 630-kVA transformer.

The three-level NPC inverter design allows using standard power transistor modules and drivers to control them. The oscillogram of line voltages generated by a three-level inverter shows that the line voltage waveform is close to a sinusoid, which provides a higher quality voltage than that of converters built on a two-level topology, all other things being equal (Teichmann and Bernet 2005).

To effectively control the power of storage batteries and capacitors, the PZR-250 MOMENTUM DC/DC charge/ discharge converter modules were included in the inverter. These modules solve the problem of matching the voltages of an energy storage unit and the DC link of an inverter module to keep the modulation index of the output harmonic voltage within the optimal range and to make the most of the stored energy.

To obtain the required discharge of the energy storage unit at minimum cost and maximum service life, the storage unit has a hybrid design with two storage types: a Li-ion battery and a supercapacitor.

At a load section of over $500 \mathrm{~kW}$ (kick-startup of a loaded DW), the supercapacitor provides a short-term discharge of up to $1,000 \mathrm{~kW}$ for up to $3 \mathrm{~s}$. A Li-ion battery is discharged when lifting the load for up to $120 \mathrm{~s}$ with a power of up to $500 \mathrm{~kW}$. Then, during an interval of up to $180 \mathrm{~s}$, the storage unit is recharged with about $133 \mathrm{~kW}$ (1C).

In this operating mode, a small part of the energy accumulated by the $133 \mathrm{kWh}$ storage battery is consumed, which allows saving the battery life, ensuring up to a few hundred thousand working charge-discharge cycles.

Another way to reduce the energy costs of a rig is to accumulate and reuse the power generated by the DW drives when lowering a drill string. Currently, this energy is dissipated on the braking resistors on all rigs.

The example of a 320 ton load capacity rig shows that when drilling a 4,000 $\mathrm{m}$ deep well, the energy dissipated on the braking resistor is $2,400 \mathrm{kWh}$. The statistics obtained through the study of various rigs show that the share of energy dissipated on the drive braking resistors may vary from just a few up to tens of percent points.

\section{Optimum integration of an ESS into a DR power supply circuit}

The chosen ESS design allows for various options of integrating it into the rig powering structure (Fig. 4). When choosing the optimum retrofit solution, several options for connecting it to power the main and auxiliary energy consumers (converters, LV distribution switchboards, automation devices, lighting, etc.) have been studied.

On a 1,000 V DC bus:

- Option \#1: charge/discharge converters + storage battery,

- Option \#2: charge/discharge converters + supercapacitors.

Both these options ensure connecting the ESS to the DC link in the system of motor control frequency converters. The advantages of this option are a higher system efficiency due to the absence of power matching transformers and inverter modules with sine filters, reduced total equipment cost, as well as the possibility of complete utilization of the energy recovered during the RIH/POOH operations. On a 690 V AC line: 
Fig. 4 Options for tying the ESS into the rig power system

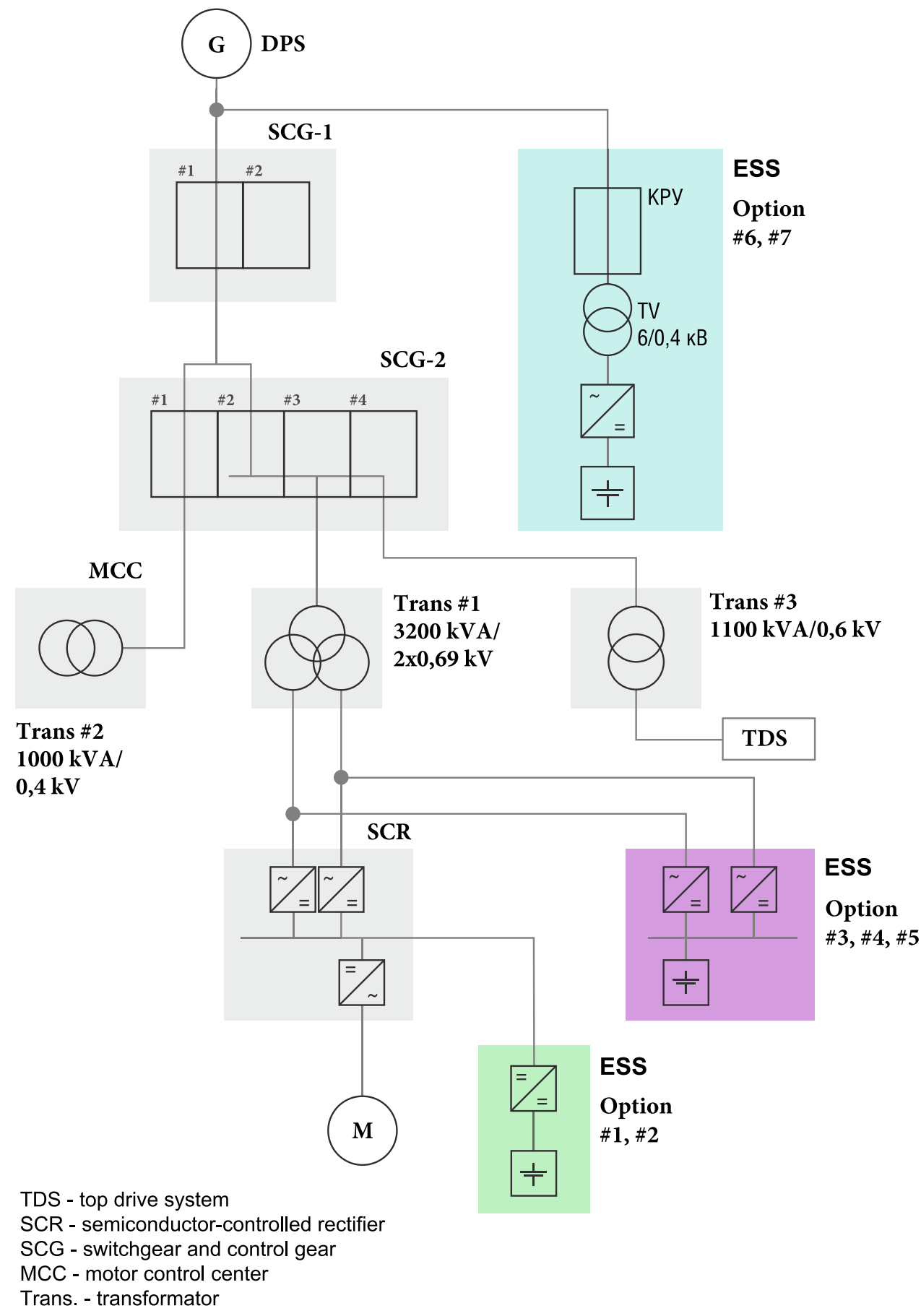

- Option \#3: active rectifier + storage battery,

- Option \#4: active rectifier + charge/discharge converters + supercapacitors,

- Option \#5: 0.6/0.6 dividing transformer + active rectifier + storage battery.

These three options ensure connecting the ESS on the $0.6 \mathrm{kV}$ side, but in this case, it is implemented using the standard switching equipment of the grid inverter, and the $\mathrm{HV}$ input cell is not required.
Notably, if active rectifiers are used as part of frequency converters to control the DW drives, there is an option to connect the ESS using recovered energy.

On a $6 \mathrm{kV}$ AC line:

- Option \#6: HV cell +6/0.4 or $6 / 0.6 \mathrm{kV}$ transformer + active rectifier + storage battery,

- Option \#7: HV cell + 6/0.6 kV transformer + active rectifier + charge/discharge converters + supercapacitors. 
Options \#6 \& \#7 ensure connecting the ESS on the $6 \mathrm{kV}$ side, in parallel connection to the diesel genset. Such a connection is considered sufficiently general-purpose yet the most expensive as the HV input cell is a must.

The impossibility of using the energy recovered during the RIH/POOH operations shall be considered a disadvantage for such an application.

Most drilling rigs with DC drives are equipped with mechanical brakes, while those with AC drives are unable to recover (return) energy to the grid (Anuchin 2015). Therefore, the accumulation and reuse of energy when lowering the drill string is possible only in newly created drives connectable to a DC link. With such a connection, both compensation of the peak drive loads and accumulation of energy during the drive regeneration are possible. This was enabled in the D-423 test drives manufactured by the Snezhinsk Factory, part of the Privodnaya Tekhnika Group.

A significant disadvantage of these circuits is their complexity, and in some cases, complete inaccessibility of DC buses of motor control frequency converters.

Considering the limited possibility of integrating the energy storage unit into the existing DRs, the option of connection via the $6 \mathrm{kV}$ AC network (i.e., option \#6) was chosen.

\section{Calculations of economic efficiency of integrating an ESS into the DPS-powered drilling rigs}

The research into the rig operating modes, as well as engineering tests, yielded a simplified mathematical model of an energy storage unit (Fig. 5) integrated into a rig power circuit.

The dependence of the decrease in the DPS running time on the storage capacity was built on the mathematical model of the storage unit, based on the experimental data analysis (Fig. 6). The diagram shows that at a storage capacity of $2 \mathrm{kWh}$, the decrease in the DPS running time does not exceed $10 \%$.

As a result, the use of a low-capacity ESS is the optimum solution since it allows achieving a minimum economic effect at relatively low costs, while the most efficient solution is using a storage unit of $150-350 \mathrm{kWh}$. The diagram shows that infinite capacity does not lead to a $100 \%$-savings since a power source is always required to cover the average daily consumption. Integrating storage systems over $1 \mathrm{MWh}$ into drilling rigs is impractical due to high cost and long payoff periods.

The data and dependencies obtained through engineering tests were used to calculate the ESS payoff periods for various utilization options and rig operating modes. The optimistic scenario is a 1.5 -year reduction for the payoff period; however, under adverse conditions, the period may extend to four years (Table 2).

\section{Summary and conclusions}

According to expert estimates, by 2025, the maximum volume of the Russian segment of the ESS market may reach USD 8.6 billion per year (realistic market estimate is USD 1.5-3 billion per year), which will bring an effect (net of investment) of USD 11 billion per year to the country's economy (USD 2.5-5 billion per year for a realistic market volume) (Udaltsov et al. 2018).

Energy storage units are the fastest growing and most promising segment in the electric power industry, given that its explosive growth started in the last 4-5 years. Herewith, several representative moments can be distinguished:

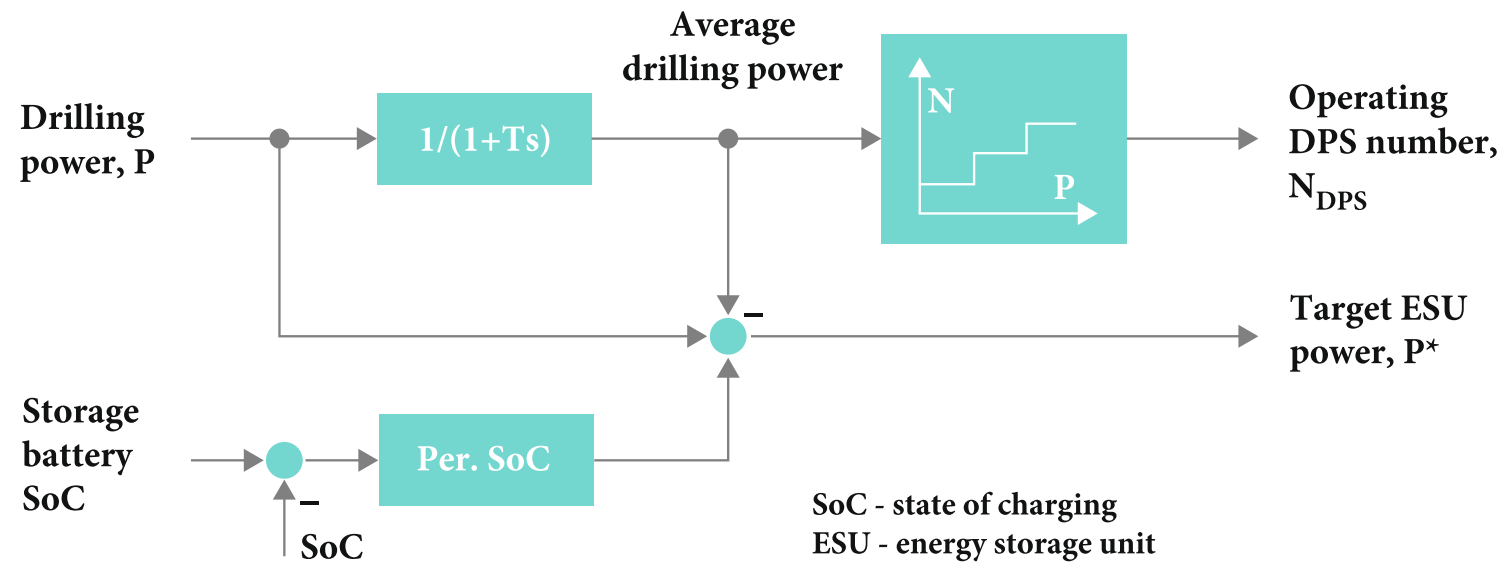

Fig. 5 Simplified mathematical model of an electric energy storage unit 
Fig. 6 Dependence of the decrease in the DPS running time on the storage capacity

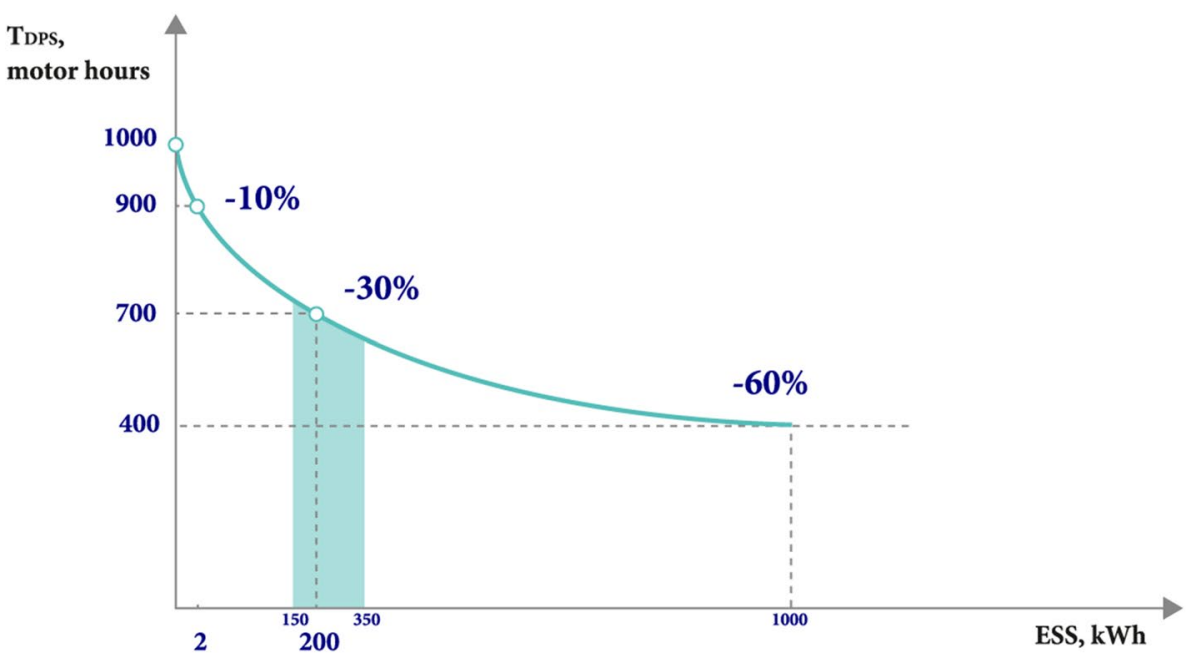

Table 2 The payoff period of ESS for drilling

\begin{tabular}{llllll}
\hline \multirow{2}{*}{$\begin{array}{l}\text { Costs for the ESS lease } \\
\text { and maintenance }\end{array}$} & \multicolumn{2}{l}{ Optimistic Scenario } & & \multicolumn{2}{l}{ Pessimistic Scenario } \\
\cline { 2 - 3 } & Savings & Savings, RUR/year & & Savings & Savings, RUR/year \\
\hline Lease & $30.0 \%$ & $12,600,000$ & & $10.0 \%$ & $4,200,000$ \\
Fuel & $6.5 \%$ & $5,850,000$ & & $2.0 \%$ & $1,800,000$ \\
Total: & & $18,450,000$ & & $6,000,000$ \\
Payoff period, years & 1.5 & & 4 & \\
\hline
\end{tabular}

a. Regulation is at a formation stage, virtually the only market mechanism that has been developed to bring storage units to the service market,

b. Over the past 3-4 years, this market has become the main catalyst for investment in storage units,

c. Currently, US and UK regulators have reduced the attractiveness of this market; the growth is shifting to other sectors, primarily to retail trade,

d. The largest growth is expected in the 'downstream of the meter' market, stimulated by subsidies for storage units and/or abolishment of subsidies for solar energy (feed-in tariff) (Rövekamp et al. 2021),

e. The market attracts not only energy companies but also investors from numerous industries, e.g., automotive and oil and gas ones, to the energy sector.

The energy storage system developed for onshore drilling is among the world's first ones. As a foreign analog, only the project of the German rig manufacturer Bentec implemented in Oman can be highlighted. In 2017, the container-type 0.9 MW Bentec ESS with a storage capacity of $0.3 \mathrm{MW}$ was put into trial operation on the KCA Deuteg T-94 rig. The best ESS operational indicators in 4 years include saving 160 ton of diesel fuel per year and reducing $\mathrm{CO}_{2}$ emissions by 420 ton.

The estimated result after a 1-year operation of the smallest ESS module in terms of storage capacity of 133
$\mathrm{kWh}$ will be saving 88 ton of diesel fuel, reducing $\mathrm{CO}_{2}$ emissions by 238 ton, or about RUR 10 million in monetary terms, given at least 10 years of ESS operation and the minimum planned fuel saving of $6.5 \%$ per year, with the expenses for maintenance, the DPS lease and capital costs included.

The main challenges for engineering improvement and the payoff period reduction of an ESS for drilling are to create effective control systems based on frequency converters that can be easily integrated into power supply circuits of existing rig (and those being developed), and to reduce the operating costs of battery cells on the back of the promising widespread introduction of silicon anodes, the transition to solid-state electrolytes, improvement of the crest factor, technological development of battery cooling systems (that allows using more cells in the unit), an increase in the storage capacity (a change in the amount of cobalt, aluminum, manganese, and nickel in the cathodes), and an increase in the cell voltage limit to $5 \mathrm{~V}$.

The main target ESS development indicators are as follows:

1. Reducing the diesel fuel consumption for powering rigs by up to 20-30\% (depending on the ESS capacity) with the overall positive economic effect compared to the exclusively DPS-powered drilling rigs,

2. Increasing the DPS TAT by up to $40 \%$, 
3. Eliminating the need to increase the drilling staff since the system is maintained by a power/electronics engineer of the drilling company,

4. High self-containment of operation - settings check once per shift,

5. Removing one or two 1 MW DPSs from service (currently, three to five such units are used),

6. The service life of frequency converters and storage batteries is at least 10 years, other elements - at least 25 years,

7. The payoff period is 2 to 5 years due to savings on diesel fuel and DPS maintenance, depending on the ESS capacity, the drilling process chart, and considering the average annual maintenance costs of RUR 0.5 million in 2020 prices,

8. Possibility of integrating ESS into all energy systems used for power rigs,

9. Possibility of operating modern energy-intensive (about $3 \mathrm{MW}$ ) rigs on weak HV lines and far from power substations without a DPS.

10. Reducing $\mathrm{CO}_{2}$ emissions from DPSs with a total capacity of $3-5 \mathrm{MW}$ by up to $25 \%$ annually.

Funding No funding was received for conducting this study.

\section{Declarations}

Conflict of interest On behalf of all the co-authors, the corresponding author states that there is no conflict of interest.

Open Access This article is licensed under a Creative Commons Attribution 4.0 International License, which permits use, sharing, adaptation, distribution and reproduction in any medium or format, as long as you give appropriate credit to the original author(s) and the source, provide a link to the Creative Commons licence, and indicate if changes were made. The images or other third party material in this article are included in the article's Creative Commons licence, unless indicated otherwise in a credit line to the material. If material is not included in the article's Creative Commons licence and your intended use is not permitted by statutory regulation or exceeds the permitted use, you will need to obtain permission directly from the copyright holder. To view a copy of this licence, visit http://creativecommons.org/licenses/by/4.0/.

\section{References}

Andrey C, El Idrissi Y, Van Nuffel L (2020) Study on energy storage - contribution to the security of the electricity supply in Europe. Publications Office of the European Union, Luxembourg

Anuchin AS (2015) Drive control systems. MPEI Publishing House, Moscow, Russia

Baccino F, Serra P, Buehler T, Kitimbo A, Morild U (2018) High-performance virtual generator BESS for distribution systems. Support applications analyzed in a hardware-in-the-loop simulation setup.
CIRED Ljubljana Workshop on Microgrids and Local Energy Communities, \#0362

Brown D, Hall S, Davis ME (2020) What is prosumerism for? Exploring the normative dimensions of decentralized energy transitions. Energy Res Soc Sci 66:10147. https://doi.org/10.1016/j.erss.2020. 101475

Chervonchenko S, Frolov V (2020) Analysis of the voltage drop of a drilling rig connected to a local energy network. J Phys Conf Ser. https://doi.org/10.1088/1742-6596/1753/1/012049

Daho T, Vaitilingom G, Ouiminga SK, Piriou B, Zongo AS, Ouoba S, Koulidiati J (2013) Influence of engine load and fuel droplet size on the performance of a CI engine fueled with cottonseed oil and its blends with diesel fuel. Appl Energy. https://doi.org/10.1016/j. apenergy.2013.05.059

Dai X, Wei K, Zhang X (2019) Analysis of the peak load leveling mode of a hybrid power system with flywheel energy storage in oil drilling rig. Energies Basel Switz. https://doi.org/10.3390/en12040606

Dehghani M, Bagheri M, Nurmanova V et al (2020) An improved PSOGA based fuzzy controller of STATCOM for cascaded induction motors of drilling system. In: EEEIC and I\&CPS Europe, Madrid, Spain. Doi: https://doi.org/10.1109/EEEIC/ICPSEurope49358. 2020.9160618

Kholkin DV, Korev DA et al (2019) The use of energy storage systems in Russia: opportunities and barriers. NTI Energinet, Moscow, Russia. https://energynet.ru/library. Accessed 23 June 2021

Northern Drilling's West Mira first rig to receive DNV GL battery (Power) class notation (2019) https://www.dnvgl.com/news/north ern-drilling-s-west-mira-first-rig-to-receive-dnv-gl-battery-powerclass-notation-161303. Accessed 23 June 2021

Pavković D, Sedić A, Guzović Z (2016) Oil drilling rig diesel powerplant fuel efficiency improvement potentials through rule-based generator scheduling and utilization of battery energy storage system. Energy Convers Manage. https://doi.org/10.1016/j.encon man.2016.05.022

Pouresmaeil E, Montesinos-Miracle D, Gomis-Bellmunt O (2012) Control scheme of three-level npc inverter for integration of renewable energy resources into AC Grid. IEEE Syst J. https:// doi.org/10.1109/JSYST.2011.2162922

Rövekamp P, Schöpf M, Wagon F, Weibelzahl M, Fridgen G (2021) Renewable electricity business models in a post feed-in tariff era. Energy. https://doi.org/10.1016/j.energy.2020.119228

Siemens Energy delivers energy storage solution for Maersk Drilling's first hybrid, low-emission jack-up drilling rig (2021) https:// electricenergyonline.com/article/energy/category/ev-storage/143/ $881500 /$ siemens-energy-delivers-energy-storage-solution-formaersk-drilling-s-first-hybrid-low-emission-jack-up-drilling-rig. html. Accessed 23 June 2021

Teichmann R, Bernet S (2005) A comparison of three-level converters versus two-level converters for low-voltage drives, traction, and utility applications. IEEE Trans Ind Appl. https://doi.org/10.1109/ TIA.2005.847285

Udaltsov Y, Kholkin D ed al (2018) Expert and analytical report distributed energy resources in Russia: development potential. Center for Strategic Research, Moscow, Russia. https://energy.skolkovo. ru/downloads/documents/SEneC/Research/SKOLKOVO_EneC_ DER_2018.10.09_Eng.pdf. Accessed 23 June 2021

Zhdaneev OV et al (2020) Technical policy issues of the Russian federation fuel and energy complex branches. Nauka, Moscow, Russia. Doi: https://doi.org/10.7868/9785020408241

Zhdaneev OV, Frolov KN (2020) Drilling technologies priorities in Russia. Oil industry, Moscow, Russia. Doi: https://doi.org/10. 24887/0028-2448-2020-5-42-48

Zhdaneev OV, Frolov KN, Konygin AE, Gekhaev MR (2020) Exploration drilling on the Arctic and Far Eastern Shelf of Russia. Arctic: ecology and economics, Moscow, Russia. Doi: https://doi.org/10. 25283/2223-4594-2020-3-112-125 
Zhuk A, Denschikov K, Fortov V, Sheindlin A, Wilczynski W (2013) Hybrid energy storage system based on supercapacitors and Li-Ion batteries. J Appl Electrochem. https://doi.org/10.1007/ s10800-013-0639-x
Publisher's Note Springer Nature remains neutral with regard to jurisdictional claims in published maps and institutional affiliations. 